\title{
PALEOBIOGEOGRAFIA E EVOLUÇÃo dOS PELECÍPODES NEOPALEOZÓICOS DA AMÉRICA dO SUL*
}

\author{
M.G.Simões \\ A.C.Rocha-Campos ${ }^{2}$
}

As biotas de invertebrados marinhos do Carbonffero e Permiano são usualmente agrupadas em três domínios paleobiogeográficos (Ártico-Boreal, Tetiano-Equatorial e GondvânicoAustral), que sofreram posteriormente desmembramento e dispersão pelos movimentos das placas litosféricas. Nesse contexto, a América do Sul (como também a África) oferece uma excelente oportunidade para estudos da paleobiogeografia do Neopaleozóico, pois no que geralmente se considera ter sido, em grande parte, uma única placa litosférica, ocorrem contiguamente assembléias de invertebrados marinhos dos domínios tetiano e gondvânico. Embora as biotas de ambos exibam acentuado provincialismo, não é rara a ocorrência de formas em comum, indicando conexões entre as duas áreas.

Assembléias de invertebrados, de caráter tipicamente tetiano, são encontradas na Venezuela e Colômbia (formações Caño Indio e Rio Palmar e unidades equivalentes), no Equador (Formação Macuma), no Peru (grupos Tarma e Copacabana, Formação Cerro Prieto), na Bolfvia (Grupo Copacabana), no Chile (camadas Juan de Morales, Calcário Tarlton e Formação Seno Eleuterio), no Brasil (formações Itaituba e Piaui). Assembléias de caráter gondvânico ocorrem na Bollvia (Formação Taiguati), na Argentina (unidades de Cordilheira Frontal, grupos San Eduardo e Tepuel, formações Bonete e Santa Elena), no Brasil (grupos Tubarão e Passa Dois), Paraguai (Formação Independência) e no Uruguai (formações Mello e Yaguari).

No geral, as faunas gondvânicas são menos diversificadas do que as tetianas,

\footnotetext{
*Apoio CNPq (Proc. 402219/89-9).

${ }^{1}$ Laboratório de Paleozoologia Evolutiva, Departamento de Zoologia, UNESP.

2Departamento de Paleontologia e Estratigrafia, Instituto de Geociências, USP.
} 
exibindo variável grau de endemismo. Embora existam na literatura diversos modelos paleobiogeográficos para o Neopaleozóico, não se dispõe ainda de metodologia consistente para a delimitação de paleoprovíncias. Assim, alguns autores têm empregado um índice de $30 \%$ de endemismo, ao nível genérico, na subdivisão das unidades biogeográficas do Paleozóico.

No Neopaleozóico da Bacia do Paraná, as assembléias de pelecípodes do Grupo Passa Dois, incluindo as malacofaunas das formações Serra Alta, Terezina, Corumbataí e da base da Formação Rio do Rasto, apresentam um índice de endemismo semelhante. Os pelecípodes da assembléia de Palaeomutela platinensis, da parte média da Formação Rio do Rasto, entretanto, parecem não ter pertencido a essa província, já que abrangem formas de águas doces, restritas aos ambientes continentais da época. Portanto, somente durante parte do tempo Passa Dois, a Bacia do Paraná teria constituído, juntamente com as bacias do Kalahari (Namíbia) e Karoo (África do Sul), uma província paleobiogeográfica distinta. Esta correspondia a um mar epicontinental, sujeito a um progressivo isolamento geográfico, cujos habitats bentônicos de águas rasas foram ocupados principalmente por pelecípodes suspensívoros, escavadores rasos e intermediários, com esporádica ocorrência de formas escavadoras profundas e da epifauna. Sua história evolutiva mostra muitos pontos de semelhança com a dos mares Negro e Cáspio, durante o Cenozóico.

É evidente, pois, que os esquemas paleobiogeográficos disponiveis, geralmente agrupando numa mesma província malacofaunas de todo o Neopaleozóico da Bacia do Paraná (grupos Tubarão e Passa Dois), "comprimem" temporalmente a informação paleobiogeográfica. Essa dificuldade em grande parte deriva da ausência de esquemas bioestratigráficos refinados, que torna necessário englobar um intervalo de tempo amplo nas reconstituições paleobiogeográficas. 